\title{
Regina and Lumsden TV Tower Bird Mortalities, 1964
}

by Fred W. Lahrman, Saskatchewan Museum of Natural History, Regina

Between August 20 and September 4, 1964, six visits were paid to the TV towers at Regina and two visits to the TV tower at Lumsden. On two of these occasions (August 21, September 4), mass kills were noted at both locations. The results of the visits are recorded below.

August 20-Checked Regina CKCK TV tower; found seven birds onlyStarling (2), Red-eyed Vireo (1), Yellow Warbler (2), Red-winged Blackbird (1), Common Grackle (1).

August 21-On the drizzling wet morning of August 21, I went first to the Regina CKCK TV tower to check for birds which might have collided with the tower and the guy wires. As soon as I arrived, I noticed a number of dead birds lying on the pavement of the driveway and parking lot. Hastily picking these up as a number had already been crushed by traffic, I soon had 30 birds collected. Then a call to the Museum brought $\mathrm{H}$. Beck, R. Carson and A. Swanston out to help and together we collected 127 birds at the CKCK tower, 36 birds at the CHRE tower (approximately two miles north of the CKCK tower), and 34 birds at the Lumsden tower. Table 1 shows the species recovered on August 21.

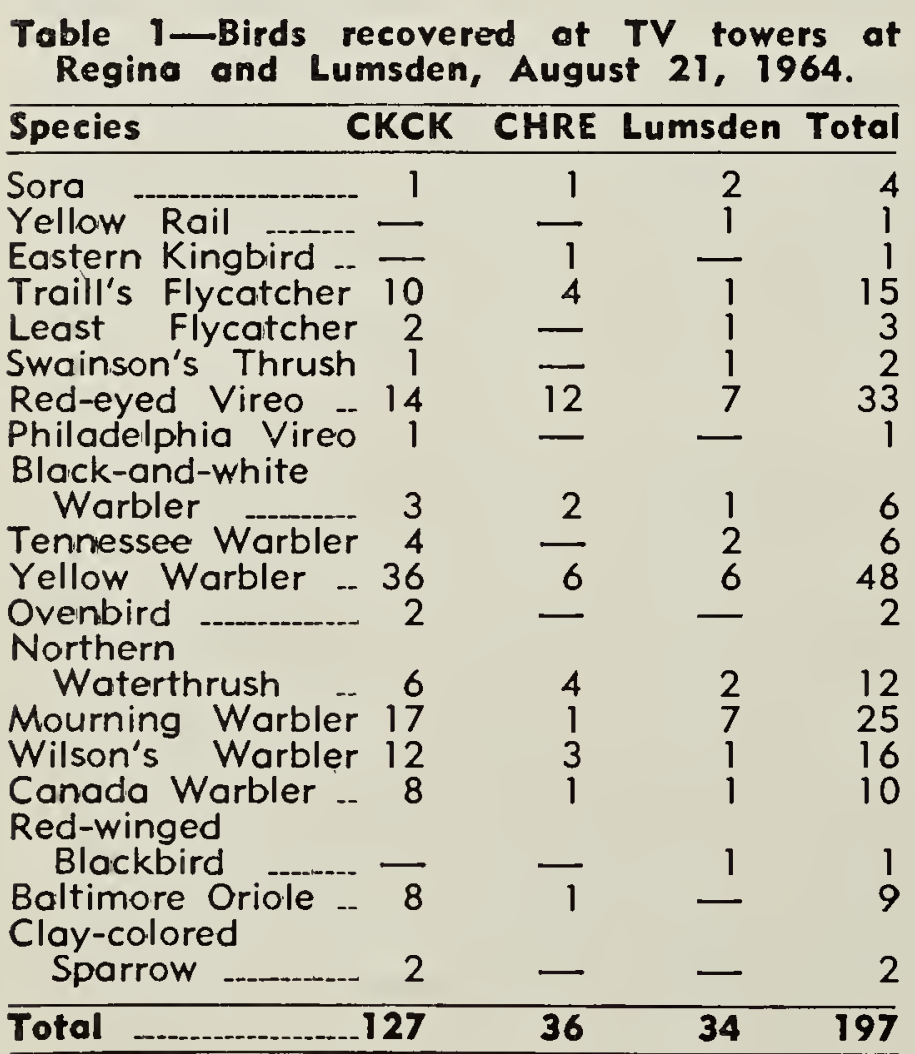

The Regina weather office reported that during the night of August 2021 when the kill apparently took place, a low pressure area was moving out. The temperature held steady from $57^{\circ}$ to $59^{\circ}$ and the wind was northerly at 8 m.p.h. There was a light drizzling rain during the night and a low cloud ceiling which varied from 500 feet to below 400 feet, so that 200 feet of the tower was in this cloud layer.

August 22-Between 11:00 p.m. and midnight, August 21, I visited the CKCK tower and found two recently killed Yellow Warblers lying on the parking lot. I could hear an almost continuous stream of warblers chirping as they passed overhead in the darkness, and possibly some were circling because of the attraction of the lights. There was no indication of any more birds being killed, but on the following day (August 22) I found the following-Sora (1), Traill's Flycatcher (2), Yellow Warbler (4), Wilson's Warbler (1).

August 24-Checked Regina CKCK TV tower. Found Yellow Warbler (1), Northern Waterthrush (1), Wilson's Warbler (2), Clay-colored Sparrow (1).

August 29-Checked Regina CKCK TV tower. Found Yellow Warbler (1), Palm Warbler (1).

September 4-On arrival at the CKCK TV tower on the bright sunny morning of September 4 I could see no evidence of any birds having been killed as there were none lying dead on the parking lot. On rounding the corner of the building I was surprised to see a great number of dead birds which had been gathered into a pile. Then I saw Dave Siggelkow picking up some more. I had met Mr. Siggelkow once previously when checking the tower for birds while he was working there and told him about the kill which had taken place on August 21. He is very interested because his business is building towers and he had no idea that they cause such mortalities. He said that when he had arrived the parking lot was littered with dead birds and that he had gath- 
ered them up so they would not be damaged by the traffic. Beck, Carson and I gathered many more in the surrounding grassy areas and stubble fields. The majority of the birds were found south and east of the tower. A total of 216 birds of 28 species was found at the CKCK tower and 77 birds of 18 species at the CHRE tower. A considerable number of injured birds were flushed from the ground. Most of these were able to fly away. Among these were noted a Catbird, Red-eyed Vireos, Northern Waterthrushes, Ovenbirds, Swamp Sparrows, and other warblers and sparrows. The Lumsden tower was also checked but no birds were found there. Table 2 shows the species recovered on September 4.

The Regina weather office reported that during the night when the kill took place the temperature held at $50^{\circ}$, the wind was NW at 20 m.p.h., barometric pressure steady at 951.8. There was a cloud layer at 4,000 feet, and a complete cloud layer at 8,000 feet all night. No rain fell.
Table 2-Birds recovered at TV towers at Regina, September 4, 1964.

\begin{tabular}{|c|c|c|c|}
\hline Species & KCK & CHRE & Total \\
\hline Virginia Rail & & - & 1 \\
\hline Sora & $i$ & 1 & 2 \\
\hline Traill's Flycatcher & 2 & 1 & 2 \\
\hline $\begin{array}{l}\text { Barn Swallow } \\
\text { Swainson's Thrush }\end{array}$ & $\overline{1}$ & $\begin{array}{l}1 \\
6\end{array}$ & $\begin{array}{l}1 \\
7\end{array}$ \\
\hline Gray-cheeked Thrush & - & 1 & 1 \\
\hline Solitary Vireo & 1 & 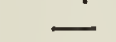 & i \\
\hline Red-eyed Vireo ...- & 30 & 9 & 39 \\
\hline & 2 & 1 & 3 \\
\hline $\begin{array}{l}\text { Warbling Vireo } \\
\text { Black-and-white Warbler }\end{array}$ & $\begin{array}{l}1 \\
3\end{array}$ & 1 & $\begin{array}{l}2 \\
4\end{array}$ \\
\hline Tennessee Warbler & 32 & 6 & 38 \\
\hline Yellow Warbler & 39 & 12 & 51 \\
\hline Magnolia Warbler & 1 & & 1 \\
\hline $\begin{array}{l}\text { Bay-breasted Warbler } \\
\text { Blackpoll Warbler }\end{array}$ & $\begin{array}{l}1 \\
6\end{array}$ & $\begin{array}{l}1 \\
6\end{array}$ & $\begin{array}{r}2 \\
12\end{array}$ \\
\hline Palm Warbler & 1 & - & 1 \\
\hline nbird & 38 & 15 & \\
\hline $\begin{array}{l}\text { Northern Waterthrush } \\
\text { Mourning Warbler }\end{array}$ & 14 & 6 & 19 \\
\hline Yellowthroat - & 5 & & 5 \\
\hline Wilson's Warbler & $\begin{array}{l}3 \\
3\end{array}$ & $?$ & 5 \\
\hline American Redstart & 2 & - & 2 \\
\hline Red-winged Blackbird & 1 & - & 1 \\
\hline Baltimore Oriole & 2 & - & 2 \\
\hline Savannah Sparrow & 1 & 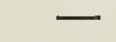 & 1 \\
\hline Sharp-tailed Sparrow & 1 & — & 1 \\
\hline Clay-colored Sparrow -- & 3 & 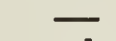 & 3 \\
\hline White-throated Sparrow & & 1 & \\
\hline Lincoln's Sparrow & 14 & 2 & 16 \\
\hline Total & 216 & 77 & 293 \\
\hline
\end{tabular}

\section{Eared Grebe Colony at Regina, 1964}

by Fred W. Lahrman, Saskatchewan Museum of Natural History, Regina

For four years we have been watching an Eared Grebe colony grow in numbers at the Regina Waterfowl Park. In 1961, 48 nests were counted (Blue Jay, 19:170-171); in 1962 the colony had a total of 165 nests (Blue Jay, 20:158); and in 1963 a total of 179 (Blue Jay, 22:17). In 1964, the highest count of Eared Grebe nests ever made in the Regina Waterfowl Park was recorded-a count of 300 .

The first Eared Grebe arrived at the Regina Waterfowl Park April 21, 1964, with an influx of Lesser Scaup, being recorded on that date along with one Horned Grebe and one Pied-billed Grebe, by Margaret Belcher. By May 2 , the grebes were established in numbers at the Waterfowl Park. On. May 27 Dot and Doug Wade counted 32 nests scattered in small groups where water plants were available in the area south of the city power house, and on May 30 they counted 122 nests. Strong winds on June 4 washed away some of the nests, but when the Wades checked the colony on June 6 they found active re-building and counted 76 nests east of the power house, with others under construction east of the Broad Street bridge. When I made my count on July 2, there was an impressive total of 300 nests. The heavy rain of .July 3 . destroyed almost all these nests and there was little renesting after. However, many grebes had already hatched and the storm did not harm thèse young birds.

\section{PRAIRIE NEST RECORDS SCHEME}

You are invited to keep nest records for the 1965 season and to submit them to the Prairie Nest Records Scheme. All records should be submitted on nest record cards which can be obtained from the Chairman, Robert Taylor. Those who contributed records in 1964 will receive cards automatically; but all new contributors should write for cards and further instructions about keeping records. Write:

ROBERT R. TAYLOR,

Chairman, Prairie Nest Records Scheme,

Box 1121,

Regina, Sask. 